\title{
Diet and feeding strategy of the dusky grouper Mycteroperca marginata (Actinopterygii: Epinephelidae) in a man-made rocky habitat in southern Brazil
}

\author{
Mario V. Condini, Elisa Seyboth, João P. Vieira and Alexandre M. Garcia
}

The dusky grouper (Mycteroperca marginata) is a marine species usually associated with rocky bottoms and reefs. The present work investigated the diet and feeding strategy of a dusky grouper population inhabiting a $4.5 \mathrm{~km}$ long pair of rocky jetties located in the mouth of Patos Lagoon estuary. No prior research has been conducted in such man-made habitat and the current study provides a basis for comparative studies on the diet of the dusky grouper populations inhabiting natural vs. manmade rocky habitats. Similarly with previous studies on natural substrates, crabs and fishes were the main food categories consumed $(\% \mathrm{IRI}=85.1$ and $\% \mathrm{IRI}=12.6$, respectively), whereas shrimps and mollusks had lower importance in the diet $(\% \mathrm{IRI}$ $=1.9$ and 0.4 , respectively). As previously reported for dusky grouper populations inhabiting reefs and rocky bottoms, the present work revealed conspicuous size related dietary shifts. Blue crabs and fishes become increasingly important food items in the diet of larger individuals ( $>500 \mathrm{~mm}, \mathrm{TL}$ ). Finally, it was found that the studied dusky population has a generalist feeding strategy with a high between-individual variation in prey consumption. Such strategy remained similar across the size increment of the species. Our findings suggest that man-made rocky substrates provide suitable feeding grounds for the dusky grouper in southern Brazil and could be used as an additional tool in the conservation efforts of this endangered species.

A garoupa-verdadeira (Mycteroperca marginata) é uma espécie marinha geralmente associada a fundos rochosos e recifes. O presente trabalho investiga a dieta e estratégia alimentar de uma população da garoupa-verdadeira que habita um longo $(4,5$ $\mathrm{km})$ par de molhes de pedra na desembocadura do estuário da laguna dos Patos, sul do Brasil. Não há trabalhos anteriores realizados nesse tipo de habitat construído pelo homem e este trabalho fornece uma base de comparação com estudos de dieta de outras populações da garoupa-verdadeira ocorrendo em habitats naturais. De modo similar ao encontrado em estudos prévios realizados em substratos naturais, caranguejos e peixes foram as principais categorias de alimento consumidas (\%IRI $=85,1 \mathrm{e} \% \mathrm{IRI}=12,6$, respectivamente), enquanto camarões e moluscos tiveram menor importância na dieta $(\% \mathrm{IRI}=1,9 \mathrm{e} \% \mathrm{IRI}$ $=0,4$, respectivamente). Como reportado anteriormente para populações de garoupa-verdadeira que habitam recifes e fundos rochosos, o presente trabalho revelou marcadas mudanças na dieta em função do tamanho da espécie. Siri-azul e peixes tornam-se gradativamente mais importantes na dieta de indivíduos maiores ( $>500 \mathrm{~mm}$ de comprimento total, CT). Finalmente, foi observado que a população de garoupa-verdadeira teve uma estratégia alimentar generalista com uma elevada variação entre indivíduos no consumo de presas. Essa estratégia permaneceu similar ao longo do aumento em tamanho da espécie. Os resultados do presente trabalho sugerem que substratos rochosos estabelecidos pelo homem propiciam locais de alimentação adequados para a garoupa-verdadeira no sul do Brasil e que poderiam ser usados como ferramentas adicionais nos esforços de conservação dessa espécie ameaçada.

Key words: Endangered species, Epinephelus marginatus, Jetties, Patos Lagoon, Stomach content analysis.

\section{Introduction}

The dusky grouper Mycteroperca marginata (formerly Epinephelus marginatus) (Actinopterygii, Epinephelidae) has a wide geographical distribution, occurring from the British Isles to South Africa, Mozambique in the Indian Ocean and in the Mediterranean Sea (Heemstra \& Randall, 1993). In the western Atlantic, its range is restricted to the southern coast of South America, from Rio de Janeiro State south to Argentina (Figueiredo \& Menezes, 1980; Rico \& Acha, 2003; Luiz Jr. et al., 2004). The 'Molhes da Barra de Rio Grande' (hereafter 'MBRG'), a man-made rock substrate (rocky jetty) $4.5 \mathrm{~km}$ long located at Rio Grande City in southern Brazil connecting a large coastal lagoon with the Atlantic Ocean, probably constitutes the southernmost limit of this species along the Brazilian coast (Condini et al., 2007). 
The dusky grouper is usually found in relatively shallow waters (up to $80 \mathrm{~m}$ deep), especially in coastal rocky substrates and reefs (Heemstra \& Randall, 1993; Paiva \& Andrade-Tubino, 1998). In southern Brazil, M. marginata is exploited by fishermen in rocky bottoms along the coastline (Haimovici et al., 1994). The rocky substrates of the MBRG harbors a population of dusky groupers that has been regularly exploited by sport and commercial fisheries and represents a significant source of income to local artisanal fishermen (Condini et al., 2007).

The dusky grouper M. marginata is currently considered as an endangered species by the International Union for Conservation of Nature (IUCN) (Cornish \& Harmelin-Vivien, 2004) and, in Brazil, the dusky grouper is considered overexploited (Brasil, 2004). Some of its biological features such as sedentary and territorial behavior (La Mesa et al., 2002), low growth rate, late maturation and protogynous hermaphrodite mode of reproduction (Fennessy, 2006) make this species particularly vulnerable to anthropogenic threats such as fishery. Accordingly, overexploitation from commercial fishing is considered the primary threat affecting this species (Cornish \& Harmelin-Vivien, 2004).

Prior research on the biological and ecological aspects of the dusky grouper M. marginata has been concentrated on populations of the Mediterranean (Marino et al., 2001; Reñones et al., 2002; Linde et al., 2004) and the African western coast (Fennessy, 2006). In Brazil, although have been recorded in São Paulo and Rio de Janeiro States (Begossi \& Silvano, 2008), previous studies have been focused on populations of Santa Catarina State, where the dusky grouper is commonly found in reefs and coastal rocky bottoms (Bertoncini et al., 2003, Gerhardinger et al., 2006; Machado et al., 2008). Previous studies regarding the diet and feeding behavior of this species in natural habitats such as reefs and coastal rocky bottoms have shown that the dusky grouper is a carnivorous fish preying upon mainly on crustaceans, cephalopods and fishes (López \& Orvay, 2005; Gibran, 2007; Machado et al., 2008). Mycteroperca marginata has crepuscular feeding habits and increases their hunting activities at twilight. They hid into the deepest region of the rocky shelters or crevices and tend to stay close to their shelters, particularly their juveniles (Gibran, 2007).

In the Rio Grande do Sul, the southernmost State of Brazil, the current knowledge regarding the dusky grouper is basically restricted to fishery aspects (Haimovici et al., 1994; Condini et al., 2007) and no prior ecological research have been done with this endangered species in this region. The main goal of the current study was to investigate diet composition, feeding strategy and size related dietary shifts of a dusky grouper population inhabiting the MBRG, which was originally built in the beginning of the twentieth-century to maintain a navigation channel between a large subtropical coastal lagoon and the sea. Our hypothesis is that diet composition and feeding strategy of dusky grouper in this man-made habitat is similar to that observed in natural rocky bottoms. No prior research on diet and feeding strategy of dusky groupers has been conducted in such man-made habitats. The current work provides a basis for comparative studies on diet of the dusky grouper populations inhabiting natural vs. man-made rocky bottoms, regarding the use of such habitats as feeding grounds for this endangered species.

\section{Material and Methods}

We adopted the recent classification of the Serranidae species proposed by Craig \& Hastings (2007) and Smith \& Craig (2007) based on molecular genetic analyses suggesting the change from genus Epinephelus to Mycteroperca. Therefore, we used M. marginata instead of E. marginatus.

The rocky jetties of the MBRG were built in 1911 using large rocks nearly 10 ton each that summed up approximately 4.5 million tons of rock after its construction (Capítoli, 1996). They are located in the Rio Grande City (Rio Grande do Sul

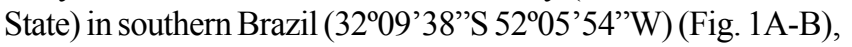
and constitutes an artificial, man-made rocky habitat that harbors a local population of dusky grouper (Condini et al., 2007) (Fig. 1C). Although precise scientific records are not available, historical accounts obtained with local fishers suggested that grouper have been caught in the MBRG at least since 1970s.

Specimens were obtained directly with local fishermen operating at the MBRG from February 2007 to May 2009 mainly during night time (between 18:00 and 07:00). See Condini et al. (2007) for a detailed description of the fishing technique employed by local fishermen in the study site. There were no individuals captured during austral winter and early spring (from June to November) due to the harsh conditions during these months. This period is characterized by higher frequency of cold fronts with wind velocities ranging from 16 to $24 \mathrm{~ms}^{-1}$ from S, SW and SE directions (Braga \& Krusche, 2000), which disfavor capture of the dusky grouper at MBRG during this time of the year. This effect is particularly strong in the western jetty (Fig. 1C), where most of the local grouper fishery occurs and from where the specimens were obtained. Fishing tended to be higher in the western jetty compared to the eastern one because the former is closer to the main fishermen village targeting this species (Condini et al., 2007).

In the laboratory, each individual was measured (total length, TL, mm), weighted (g) and dissected to extract its stomach, which was preserved in $10 \%$ formaldehyde and stored in $70 \%$ alcohol a week later for posterior analysis. Food items found in each stomach were identified to the lower possible taxonomic level. Each stomach was weighted before and after its content being removed. For each food item found in the stomach, it was recorded their numerical abundance, weight $(0.01 \mathrm{~g}$ precision) and TL $(\mathrm{mm})$. The prey's TL was measured only when the prey was not broken in pieces or was too digested. Food items were pooled in the following major food categories: non-blue crabs (all brachyuran crabs except Callinects spp.), blue crabs (Callinects sapidus, $C$. danae), fishes, shrimps and mollusks. 

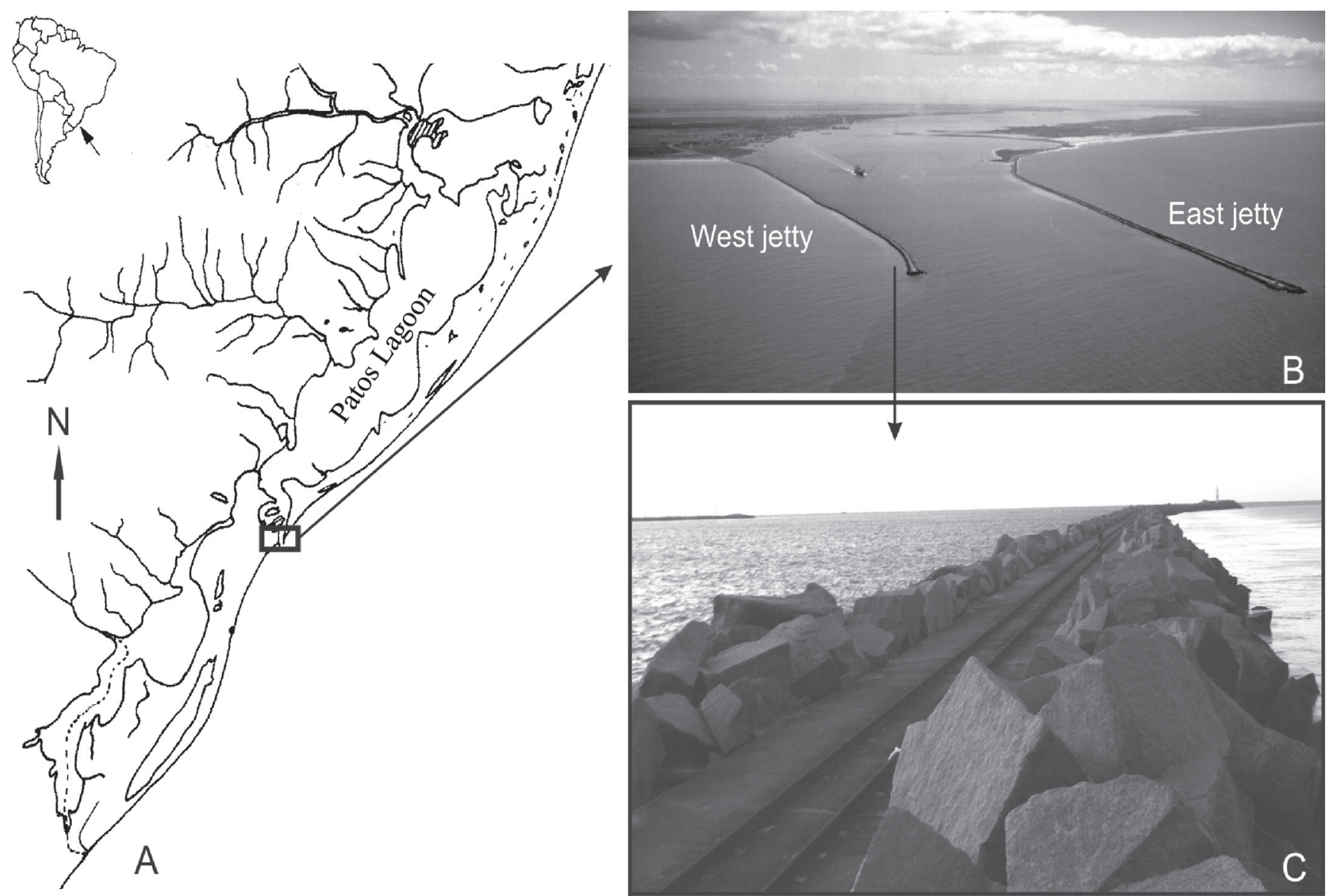

Fig. 1. Patos Lagoon $\left(10.360 \mathrm{~km}^{2}\right)$ in southern Brazil (A) and the $4.5 \mathrm{~km}$ long pair of jetties that connects the estuarine zone of the lagoon with the Atlantic Ocean (B), detail of the west jetty and their large pieces of rock nearly 10 ton each $(\mathbf{C})$. These rocky jetties are located in the Rio Grande City (Rio Grande do Sul State) in southern Brazil.

Food items and food categories were quantified using the following parameters (Hyslop, 1980): (a) frequency of occurrence $(\% \mathrm{~F})$ that represents the number of non-empty stomachs (in percentage) that a particular food item or food category was found, (b) numerical abundance $(\% \mathrm{~N})$ that represents the total number (in percentage) of an particular food item or food category in relation to the total number of food items or food category found in all non-empty stomachs and (c) weight $(\% \mathrm{~W})$ that represents the total weight (in percentage) of an particular food item or food category in relation to the total number of food items or food categories found in all nonempty stomachs (Hyslop, 1980). These parameters were used to calculate the Index of Relative Importance (\%IRI) proposed by Pinkas et al. (1971): \% $\mathrm{IRI}=\% \mathrm{~F} *[\% \mathrm{~N}+\% \mathrm{~W}]$.

In order to assess diet changes related to differences in predator's size (TL, mm), individuals of $M$. marginata were pooled into three size classes: $<400 \mathrm{~mm} ; 400-500 \mathrm{~mm}$ and $>$ $500 \mathrm{~mm}$ (adapted from Linde et al., 2004; Machado et al., 2008). The number of individuals analyzed in each size class was 29,34 and 15, respectively. The \%IRI for each food category was computed for each size class. One-way ANOVA was used to evaluate differences in the average prey's size and biomass among the three predefined size classes and post-hoc differences were evaluated using the Newman-Keuls test $(\alpha=0.05)$. ANOVA's assumptions of normality and homogeneity of variance were assessed via the KolmogorovSmirnov and Cochran tests, respectively (Zar, 1994).

The graphical analysis proposed by Amundsen et al. (1996) was employed to analyze feeding strategy and to evaluate the contribution of each individual (phenotype) to population niche width (Deus \& Petrere-Junior, 2003; Garcia et al., 2005). This approach is based on a two-dimensional representation of prey-specific abundance $\left(\mathrm{P}_{\mathrm{i}}\right)$ and $\% \mathrm{~F}$ of the different prey types in the diet. The 'prey-specific abundance of prey' $\left(\mathrm{P}_{\mathrm{i}}=\left(\Sigma \mathrm{S}_{\mathrm{i}} / \Sigma \mathrm{S}_{\mathrm{ti}}\right) \times 100\right)$ take into account only those predators in which the actual prey occurs; where $P_{i}$ is the prey-specific abundance of prey $\mathrm{i}, \mathrm{S}_{\mathrm{i}}$ is the stomach content (weight) comprised of prey $\mathrm{i}$, and $\mathrm{S}_{\mathrm{ti}}$ is the total stomach content in only those predators with prey $i$ in their stomach (Amundsen et al., 1996). We employed the Amundsen et al.'s diagram to the different size classes defined above.

\section{Results}

\section{Diet composition}

A total of 133 individuals of M. marginata ranging from 260 to $800 \mathrm{~mm}$ TL $(443 \pm 100.7 \mathrm{~mm})$ had its stomach content analyzed and only 78 had food content. Inspection of these non-empty 
stomachs revealed 31 food items belonging to the classes Gastropoda and Bivalvia and subclasses Malacostraca and Actinopterygii (Table 1). In general, crustaceans of the Brachyura infraorder were the most frequent and abundant item in the stomach content, both in terms of their volumetric and numerical contributions (Table 1). Non-blue crabs, in particular, represented an important and diverse group in the diet, especially species of the Xanthidae family. For instance, the stone crab Menippe nodifrons was the most important item in the diet $(\% \mathrm{IRI}=24.1)$, occurring in $18.2 \%$ of the non-empty stomachs. Blue crabs (Callinectes sapidus and C. danae) were also conspicuous items in the diet $(\% \mathrm{IRI}=11.6$ and 6.6,

Table 1. Numerical abundance $(\% \mathrm{~N})$, weight $(\% \mathrm{~W})$, frequency of occurrence $(\% \mathrm{~F})$ and the Index of Relative Importance (IRI\%) for each food item found in the stomach content of the dusk grouper Mycteroperca marginata individuals captured. $\mathrm{N}=78$ non-empty stomachs.

\begin{tabular}{|c|c|c|c|c|c|}
\hline Prey items & & $\% \mathrm{~F}$ & $\% \mathrm{~N}$ & $\% \mathrm{~W}$ & IRI\% \\
\hline \multicolumn{6}{|l|}{ Mollusca } \\
\hline \multicolumn{6}{|c|}{ Gastropoda } \\
\hline & Anachis isabellei & 1.30 & 0.56 & 0.05 & 0.03 \\
\hline & Anachis spp. & 2.60 & 2.22 & 0.23 & 0.25 \\
\hline \multicolumn{6}{|l|}{ Bivalvia } \\
\hline & Mytilus edulis platensis & 2.60 & 1.11 & 0.00 & 0.11 \\
\hline & Perna perna & 1.30 & 0.56 & 0.08 & 0.03 \\
\hline & Ostrea equestris & 1.30 & 0.56 & 0.03 & 0.03 \\
\hline & Bivalve unidentified & 2.60 & 1.11 & 0.18 & 0.13 \\
\hline \multicolumn{6}{|c|}{ Crustacea } \\
\hline \multicolumn{6}{|c|}{ Dendrobranchiata } \\
\hline \multicolumn{6}{|c|}{ Solenoceridae } \\
\hline & Pleoticus muelleri & 3.90 & 3.33 & 1.07 & 0.67 \\
\hline \multicolumn{6}{|c|}{ Anomura } \\
\hline \multicolumn{6}{|c|}{ Porcellanidae } \\
\hline & Pachycheles chubutensis & 1.30 & 0.56 & 0.26 & 0.04 \\
\hline \multicolumn{6}{|c|}{ Brachyura } \\
\hline \multicolumn{6}{|c|}{ Majidae } \\
\hline & Libinia spinosa & 5.19 & 2.78 & 0.77 & 0.72 \\
\hline \multicolumn{6}{|c|}{ Portunidae } \\
\hline & Arenaeus cribrarius & 1.30 & 0.56 & 0.06 & 0.03 \\
\hline & Callinectes danae & 9.09 & 7.22 & 11.26 & 6.53 \\
\hline & Callinectes sapidus & 12.99 & 7.22 & 15.67 & 11.55 \\
\hline & Callinectes sp. & 5.19 & 2.22 & 1.32 & 0.71 \\
\hline \multicolumn{6}{|c|}{ Xanthidae } \\
\hline & Eurypanopeus abbreviatus & 5.19 & 2.22 & 6.02 & 1.66 \\
\hline & Hexapanopeus schmidt & 3.90 & 1.67 & 0.34 & 0.30 \\
\hline & Hexapanopeus caribbaeus & 1.30 & 0.56 & 0.03 & 0.03 \\
\hline & Menippe nodifrons & 18.18 & 12.78 & 21.33 & 24.10 \\
\hline & Panopeus austrobesus & 6.49 & 3.89 & 3.98 & 1.98 \\
\hline & Xanthidae unidentified & 7.79 & 3.89 & 1.10 & 1.51 \\
\hline & Varunidae & & & & \\
\hline & Cyrtograpsus altimanus & 1.30 & 0.56 & 0.03 & 0.03 \\
\hline & Pilumnidae & & & & \\
\hline & Pilumnus dasypodus & 5.19 & 2.78 & 0.50 & 0.66 \\
\hline \multicolumn{6}{|l|}{ Caridea } \\
\hline & Hippolytidae & & & & \\
\hline & Lysmata wurdremanni & 3.90 & 1.67 & 0.44 & 0.32 \\
\hline & Caridea unidentified & 6.49 & 6.11 & 1.93 & 2.03 \\
\hline & Decapoda unidentified & 23.38 & 13.89 & 9.34 & 21.10 \\
\hline \multicolumn{6}{|l|}{ Actinopterygii } \\
\hline & Hypleurochilus fissicorni & 6.49 & 2.78 & 1.90 & 1.18 \\
\hline & Gobionellus sp. & 1.30 & 0.56 & 0.05 & 0.03 \\
\hline & Umbrina canosai & 1.30 & 0.56 & 0.02 & 0.03 \\
\hline & Lycengraulis grossidens & 1.30 & 0.56 & 3.37 & 0.20 \\
\hline & Genidens barbus & 1.30 & 1.67 & 4.20 & 0.30 \\
\hline & Porichthys porosissimus & 1.30 & 0.56 & 0.17 & 0.04 \\
\hline & Actinopterygii unidentified & 22.08 & 13.33 & 14.26 & 23.67 \\
\hline
\end{tabular}

respectively). Aside crustaceans, fishes were another important prey in the dusky grouper's diet, with six fish species found in the stomach content.

\section{Size related dietary shift}

The relative importance of food categories in the diet changed across different size classes of the dusky grouper. The relative importance of 'non-blue crabs' decreased steadily across size classes and 'blue crabs', fishes and, in lesser extent, shrimps become increasingly important food items in the diet of larger individuals, particularly in the $>500$ $\mathrm{mm}$ size class (Fig. 2). Accordingly, prey's size and biomass found in the stomach content changed across size classes of the dusky grouper (Fig. 3). Prey's average sizes (TL, mm) showed significant differences across predator's size classes $(F(2,124)=7.292, p<0.001)$, being statistically significant higher in the larger size classes (400-500 and $>500)$ compared to individuals of the smallest size class $(<400 \mathrm{~mm}$ ) (NewmanKeuls test, $\alpha=0.05$ ). A similar increasing trend was found for preys' average biomasses, but there were no statistically differences in prey biomass among size classes (NewmanKeuls test, $\alpha=0.05$ ) (Fig. 3).

According to the Amundsen et al.'s diagram, the dusky grouper had a generalist feeding strategy characterized by a high variability in prey consumption between individuals (phenotypes). By and large, this feeding strategy did not change among size classes of the dusky grouper, but there were differences in the prey taxa that were opportunistically consumed in each size class (Fig. 4). Smaller dusky grouper individuals $(<400 \mathrm{~mm})$ preyed upon occasionally $(\% \mathrm{~F}<0.20)$ on an array of 'non-blue crabs' species and only once preyed on 'blue-crab' (\%F: 0.04) (Fig. 4A). In contrast, 'blue-crabs' became increasingly frequent and abundant in the diet of larger individuals of size classes $400-500(\% \mathrm{~F}: 0.32)$ and $>500$ $\mathrm{mm}(\% \mathrm{~F}: 0.40)$. Additionally, among those preys consumed opportunistically (i.e., preys with low frequency of occurrence and higher prey-specific abundance values), larger dusky grouper individuals switched to 'fishes' and other 'non-blue crabs'. For instance, individuals between $400-500 \mathrm{~mm}$ consumed opportunistically the Atlantic sabretooth anchovy Lycengraulis grossidens and the lobate mud crab Eurypanopeus abbreviatus, whereas individuals $>500$ fed occasionally on juveniles of the white sea catfish Genidens barbus and the stone crab Menippe nodifrons. Therefore, the analysis of the feeding strategy revealed a considerable amount of variation in the prey consumption among individuals, which suggest greater partitioning of the food resources between individuals of the population. According to the Amundsen et al.'s diagram this configuration reveals a wide food niche where different individuals specialize on different resource types (Fig. 4A, inserted box).

\section{Discussion}

The high frequency of empty stomachs (41.3\%) found in the present work is in the range of values reported in studies 


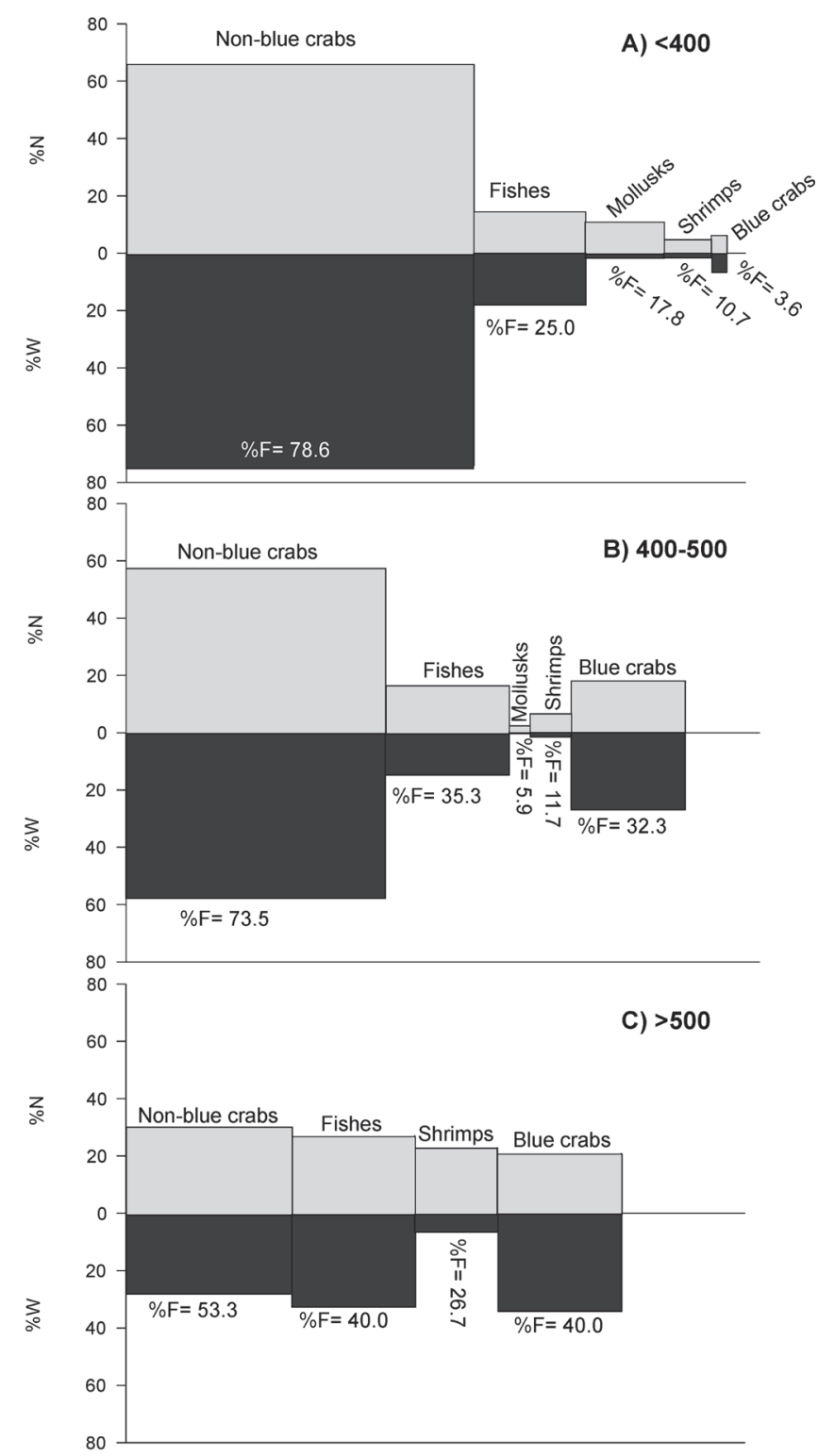

Fig. 2. Components $(\% \mathrm{~N}, \% \mathrm{~W}, \% \mathrm{~F})$ of the Index of Relative Importance (\%IRI) for each of the five major categories of food found in the stomach content of three size classes (A: $<400 \mathrm{~mm}$ TL; B: $400-500 \mathrm{~mm}$ TL; C: $>500 \mathrm{~mm}$ TL) of the dusky grouper Mycteroperca marginata. The number of individuals analyzed in each size class is 29,34 and 15, respectively. Mollusks did not occur in the larger size class (> $500 \mathrm{~mm}$ TL).

elsewhere, from $17.5 \%$ (López \& Orvay, 2005) to 56.1\% (Reñones et al., 2002). This variability could be explained by the hypothesis that different fishing methods employed to obtain the fishes (e.g., speargun, hook, and line) could lead to different rates of regurgitation of captured individuals. Alternatively, these differences could be related with ecological factors as differences in food resources availability or seasonality in each site. Nevertheless, a high frequency of empty stomachs is usually higher in carnivorous fishes when compared to detritivorous and omnivorous fishes (Arrington et al., 2002).
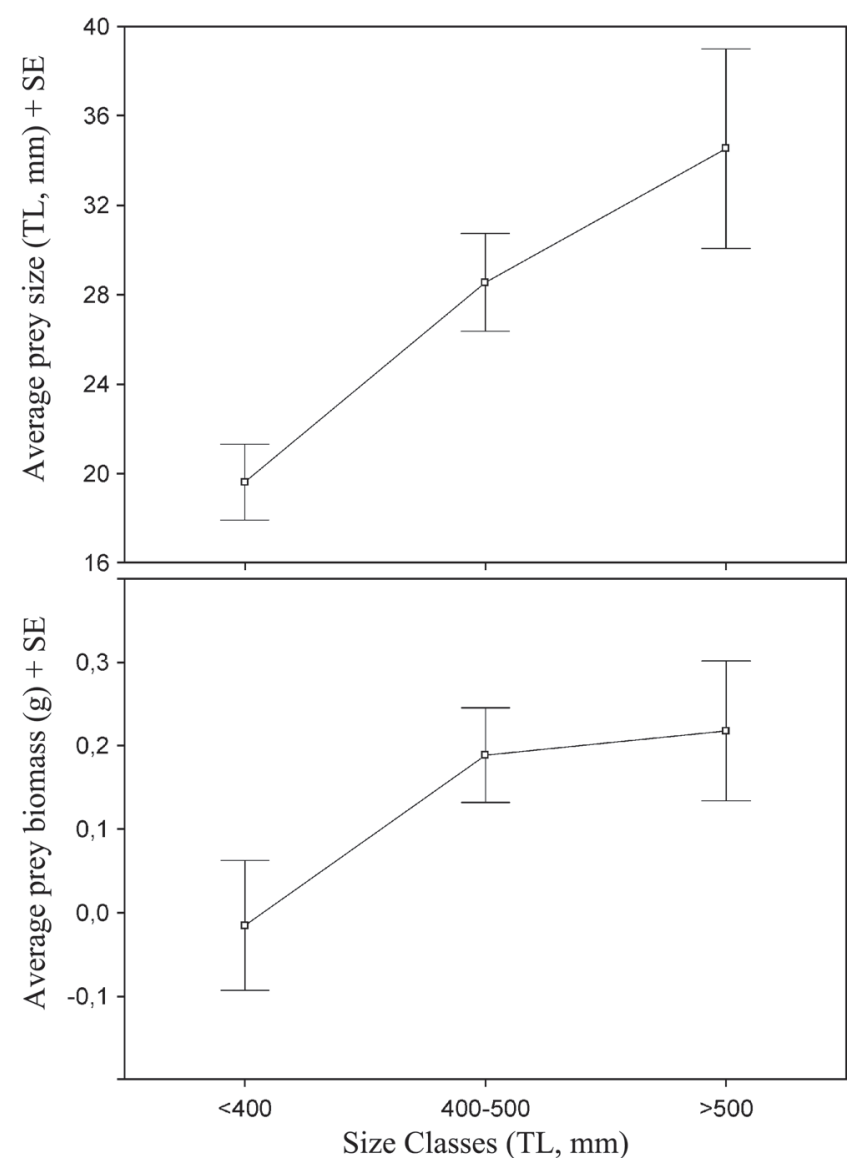

Fig. 3. Average values $( \pm \mathrm{SD})$ of prey's size (mm, TL) and biomass $(\mathrm{g})$ in the stomach content of three size classes $(<400$ $\mathrm{mm}$ TL; 400-500 mm TL; $>500 \mathrm{~mm}$ TL) of the dusky grouper Mycteroperca marginata. The number of individuals analyzed in each size class is 29,34 and 15 , respectively.

Brachyuran crabs were the main food items in the diet of the dusky grouper individuals inhabiting the man-made rock bottoms at MBRG, which is consistent with results found in natural rocky bottom and reefs habitats elsewhere. For instance, Linde et al. (2004) showed that brachyuran crabs occurred in $50.4 \%$ of the analyzed stomachs of the dusky population of the islands of Majorca and Minorca in the Mediterranean Sea. Similarly, Machado et al. (2008) found brachyuran crabs in $83.7 \%$ of the individuals collected along the coastline of Santa Catarina State in southeastern Brazil. There were differences, however, in the specific brachyuran species consumed in each region. Dusky grouper individuals of the MBRG consumed mainly the stone crab M. nodifrons, whereas in the Santa Catarina coast the red swimming crab Cronius rubber was the most common brachyuran crab in the diet (Machado et al., 2008). Also similar with studies elsewhere, it was found that ray-finned fishes were a conspicuous food item in the diet of the dusky grouper. For instance, studies in natural reefs and rocky bottoms of the Mediterranean Sea showed that fish preys occurred with frequencies of 33.3\% (López \& Orvay, 2005) and 44.3\% (Linde 


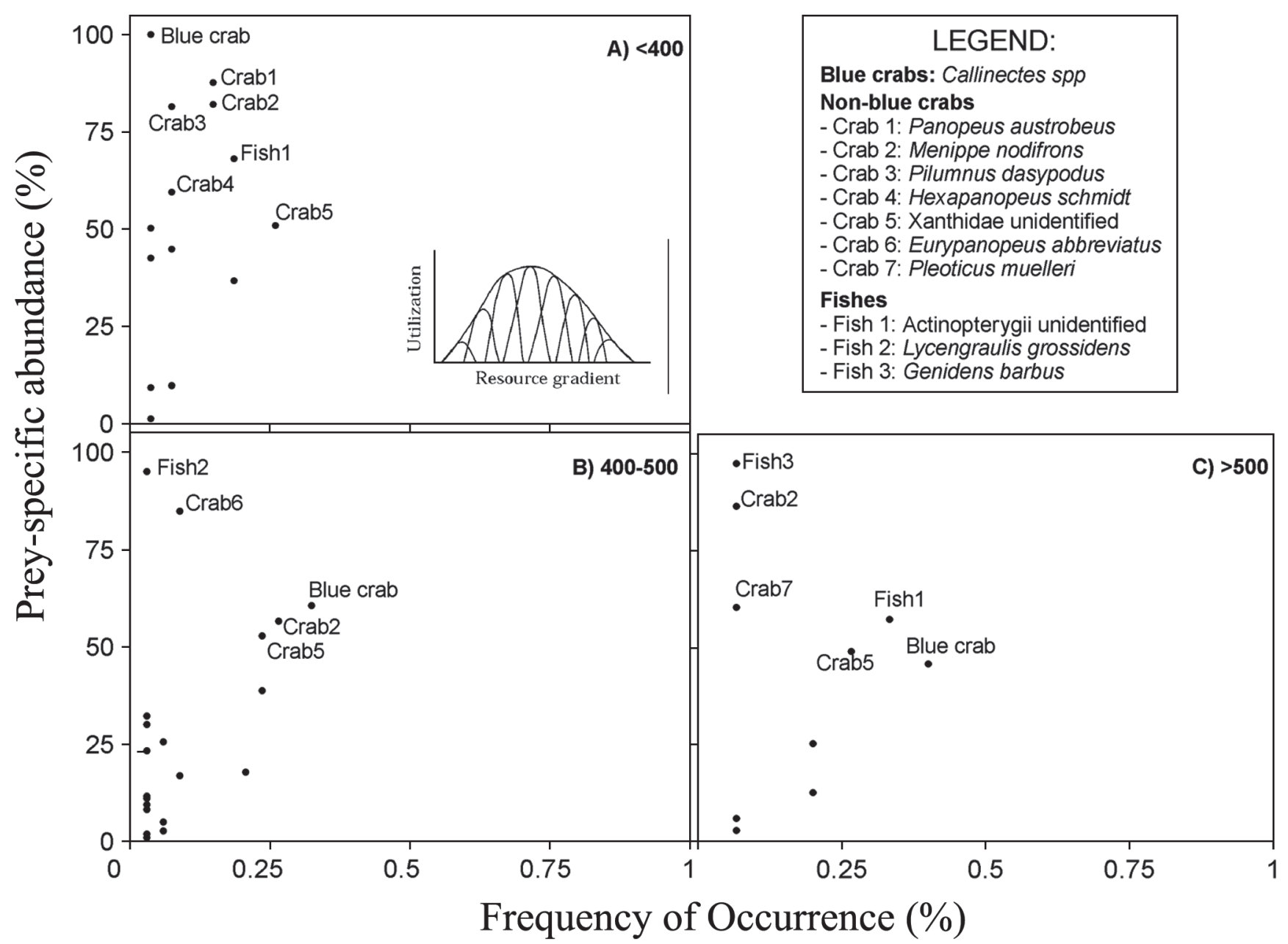

Fig. 4. Feeding strategy diagram for individuals of three size classes (A: $<400 \mathrm{~mm}$ TL; B: $400-500 \mathrm{~mm}$ TL; C: $>500 \mathrm{~mm}$ TL) of the dusky grouper Mycteroperca marginata. Prey-specific abundance plotted against frequency of occurrence of food items in the diet of the dusky grouper. The inserted boxed (A) represents a conceptual diagram of a resource niche width characterized by a high between-phenotype component (sensu Amundsen et al., 1996) to niche width contribution. The number of individuals analyzed in each size class is 29,34 and 15 , respectively.

et al., 2004), whereas values of $35.0 \%$ have been reported for populations in southeastern Brazil (Machado et al., 2008).

Regarding cephalopod preys, however, there were important differences between the findings of the current work and studies on dusky grouper populations elsewhere. In contrast with most studies pointing out cephalopods as a common prey in the diet of the dusky grouper (Barreiros \& Santos, 1998; Harmelin \& Harmelin-Vivien, 1999; Reñones et al., 2002; Linde et al., 2004; López \& Orvay, 2005), these prey taxa were not found in the stomach content of the individuals inhabiting the studied man-made rocky bottom (MBRG). In southern Brazil, squids (e.g., Illex argentinenis, Loligo sanpaulensis) and octopuses (e.g., Octopus vulgares, O. tehuelchus) are usually found along the continental shelf and continental slope (Haimovici \& Álvarez-Perez, 1990; Andriguetto \& Haimovici, 1996; Santos \& Haimovici, 1997; Santos \& Haimovici, 2002), but they are presumably absent in the shallow waters $(<10 \mathrm{~m})$ where the studied site (MBRG) is located. Other mollusks, such as bivalves and gastropods, were found in the stomach content of the dusky grouper at MBRG. However, these preys had very low frequency $(<10 \%)$ in the analyzed stomachs, a pattern also reported by Reñones et al. (2002) and Machado et al. 2008). Some authors (Linde et al., 2004) argued that these preys, together with barnacles and vegetation, had low abundance in the dusky grouper's stomach content because they would be accidentally ingested when they are preying upon their targeted preys such as crabs, fishes and cephalopods.

Feeding strategy analysis revealed that the studied dusky grouper population had a generalist feeding behavior characterized by a strong opportunism of some individuals in the populations towards the consumption of certain preys. The degree of opportunism, particularly in the consumption of brachyuran crabs, seemed to be greater in smaller individuals $(<400 \mathrm{~mm})$ than in larger individuals, which seemed to concentrate their feeding on larger preys as blue 
crabs and fishes. Regardless predator size, the studied dusky population has a general feeding strategy with a high between-individual (or phenotypes) variation in prey consumption. This feeding strategy has been also found for dusky grouper populations of the Mediterranean Sea (Linde et al., 2004) and southeastern Brazil (Machado et al., 2008). Individual-level niche variation only recently has been considered as a feeding strategy to avoid conspecific competition (Bolnick et al., 2003). Future studies should evaluate the importance of individual feeding specialization in controlling food resource partitioning among individuals of dusky grouper populations.

As previously reported for dusky grouper populations inhabiting reefs and rocky bottoms, the present work revealed conspicuous size related dietary shifts. However, whereas prior studies have shown that cephalopods are usually found in the stomach of intermediate and larger sizes individuals (Reñones et al., 2002; Machado et al., 2008), the current work showed that larger preys as blue crabs and fishes become increasingly important food items in the diet of larger individuals. According to Linde et al. (2004), the dusky grouper's efficiency in capturing larger and more mobile preys such as blue crabs seemed to increase proportionally with its increment in size (TL). This presumably higher efficiency in capturing larger preys by larger specimens could compensate the greater demand for energy expected to occur in adult individuals involved with reproduction and/or territorial patrolling activities.

In summary, our findings reveals that a dusky grouper population inhabiting a man-made rocky habitat has a similar feeding ecology in terms of diet composition, feeding strategy and size related dietary changes when compared with populations studied in reefs and natural rocky bottoms. Differences in the consumed preys were observed mainly at the species level, which could be related with differences in geographic distribution or local abundance patterns of consumed preys. Regarding feeding strategy, the studied dusky population has a general feeding strategy with a high between-individual (or phenotypes) variation in prey consumption that remained similar across their life time. These findings suggest that man-made rocky substrates as the MBRG in southern Brazil could provide suitable feeding grounds for this endangered species. Future studies should investigate the ecological role played by other rocky jetties for dusky grouper populations elsewhere.

\section{Acknowledgements}

We thank Rony R. Vieira and other colleagues of the Laboratório de Crustáceos Decapodes of the Oceanographic Institute of the Federal University of Rio Grande (FURG) who have assisted in the taxonomic identification of the crustaceans, to local fishermen for their assistance in the field and to three anonymous reviewers for their comments. The study received financial support of the Fundação O Boticário de Proteção a Natureza through a research fellowship (0753-20072).

\section{Literature Cited}

Amundsen, P. A., H. M. Gabler \& F. J. Staldvik. 1996. A new approach to graphical analysis of feeding strategy from stomach contents data - modification of the Costello (1990) method. Journal of Fish Biology, 48: 607-614.

Andriguetto, J. \& M. Haimovici. 1996. Reproductive cycle of Loligo sanpaulensis Brakoniecki, 1984 (Cephalopoda; Loliginidae) in southern Brazil. Scientia Marina, 60(4): 443-450.

Arrington, D. A., K. O. Winemiller, W. F. Loftus \& S. Akin. 2002. How often do fishes "run on empty"?. Ecology, 83(8): 2145-2151.

Barreiros, J. P. \& R. S. Santos. 1998. Notes on the food habits and predatory behavior of the dusky grouper, Epinephelus marginatus (Lowe, 1834) (Pisces: Serranidae) in the Azores, Arquipélago. Life and Marines Sciences, 16(A): 29-35.

Begossi, A. \& R. A. Silvano. 2008. Ecology and ethnoecology of dusky grouper [garoupa, Epinephelus marginatus (Lowe, 1834)] along the coast of Brazil. Journal of ethnobiology and ethnomedicine, 4(20): 1-14.

Bertoncini, A. A., L. F. Machado, M. Hostim-Silva \& J. P. Barreiros. 2003. Reproductive biology of the dusky grouper Epinephelus marginatus (Lowe, 1834). Brazilian Archives of Biology and Technology, 46(3): 373-381.

Bolnick, D. I., R. Svanbäck, J. A. Fordyce, L. H. Yang, J. M. Davis, C. D. Hulsey \& M. L. Forister. 2003. The ecology of individuals: incidence and implications of individual specialization. The American Naturalist, 161(1): 1-20.

Braga, M. F. S. \& N. Krusche. 2000. Padrão de Ventos em Rio Grande, RS, no período de 1992 a 1995. Atlântica, 22: 27-40.

Brasil, 2004. Ministério do Meio Ambiente. Instituto Brasileiro do Meio Ambiente e dos Recursos Naturais Renováveis (IBAMA). Instrução Normativa $n^{\circ} 3$. Ministério do Meio Ambiente, Brasília.

Capítoli, R. R. 1996. Rubble structures and hard substrates. Pp. 86-89. In: Seeliger, U., C. Odebrecht \& J. P. Castello (Eds.). Subtropical Convergence Environments: The Coast and Sea In The Southwestern Atlantic. Berlim, SpringerVerlag, 308p.

Condini, M. V., A. M. Garcia \& J. P. Vieira. 2007. Perfil do pescador e descrição da pesca da garoupa (Pisces, Serranidae) no Molhe Oeste da Barra de Rio Grande, RS. Pan-American Journal of Aquatic Sciences, 2(3): 279-287.

Cornish, A. \& M. Harmelin-Vivien. 2004. Epinephelus marginatus. 2006 IUCN Red List of Threatened Species. <www.iucnredlist.org>.

Craig, M. T. \& P. A. Hastings. 2007. A molecular phylogeny of the groupers of the subfamily Epinephelinae (Serranidae) with a revised classification of Epinephelini. Ichthyological Research, 54: 1-17.

Deus, C. P. \& M. Petrere-Junior. 2003. Seasonal diet shift of seven fish species in an Atlantic rainforest stream in southeastern Brazil. Brazilian Journal of Biology, 63(4): 579-588.

Fennessy, Y. S. T. 2006. Reproductive biology and growth of the yellowbelly rockcod Epinephelus marginatus (Serranidae) from South-east Africa. African Journal of Marine Science, 28(1): 1-11.

Figueiredo, J. L. \& N. A. Menezes. 1980. Manual de peixes marinhos do sudeste do Brasil. III. Teleostei (2). Museu de Zoologia, Universidade de São Paulo, 90p.

Garcia, A. M., R. M. Geraldi \& J. P. Vieira. 2005. Diet composition and feeding strategy of the southern pipefish Syngnathus folletti in a widgeon grass bed of the Patos Lagoon Estuary, RS, Brazil. Neotropical Ichthyology, 3(3): 427-432. 
Gerhardinger, L. C., M. O. Freitas, A. A. Bertoncini \& M. HostimSilva. 2006. Collaborative approach in the study of the reproductive biology of the dusky grouper Epinephelus marginatus (Lowe, 1834) (Perciformes: Serranidae). Acta Scientiarum - Biological Sciences, 28(3): 219-226.

Gibran, F. Z. 2007. Activity, habitat use, feeding behavior, and diet of four sympatric species of Serranidae (Actinopterygii: Perciformes) in southeastern Brazil. Neotropical Ichthyology, 5(3): 387-398.

Haimovici, M. \& J. A. Álvarez-Pérez. 1990. Distribución y maduración sexual del calamar argentino, Illex argentinus (Castellanos, 1960) (Cephalopoda: Ommastrephidae), em el sur de Brasil. Scientia Marina, 54(2): 179-185.

Haimovici, M., A. S. Martins, J. L. Figueiredo \& P. C. Vieira. 1994. Demersal bony fish of the outer shelf and upper slope of the southern Brazil subtropical convergence ecosystem. Marine Ecology Progress Series, 108: 59-77.

Harmelin, J. \& M. Harmelin-Vivien. 1999. A review on habitat, diet and growth of the dusky grouper Epinephelus marginatus (Lowe, 1834). Marine Life, 9(2): 11-20.

Heemstra, C. P. \& J. E. Randall. 1993. FAO Species catalogue. Groupers of the word (Family Serranidae, Subfamily Epinephelinae, An Annotated and Illustred Catalogue of the Grouper, Rockcod, Hind, Coral grouper Lyretail Species. FAO Fisheries Synopsis, 16: 186-189.

Hyslop, E. J. 1980. Stomach contents analysis - a review of methods and their application. Journal of Fish Biology, 17: 411-429.

La Mesa, G., P. Louisy \& M. Vacchi. 2002. Assessment of microhabitat preferences in juvenile dusky grouper (Epinephelus marginatus) by visual sampling. Marine Biology, 140(1): 175-185.

Linde, M., A. M. Grau, F. Riera \& E. Massutí-Pascual. 2004. Analysis of trophic ontogeny in Epinephelus marginatus (Serranidae). Cybium, 28(1): 27-35.

López, V. G. \& F. C. Orvay. 2005. Food habits of groupers Epinephelus marginatus (Lowe, 1834) and Epinephelus costae (Steindachner, 1878) in the Mediterranean Coast of Spain. Hidrobiológica, 15(1): 27-34.
Luiz Jr., O. J., S. R. Floeter, C. E. L. Ferreira, J. L. Gasparini \& P. Wirtz. 2004. The occurrence of Acanthurus monroviae (Perciformes: Acanthuridae) in the southwestern Atlantic, with comments on other eastern Atlantic reef fishes occurring in Brazil. Journal of Fish Biology, 65: 1173-1179.

Machado, L. M., F. A. M. L. Daros, A. A. Bertoncini, M. HostimSilva \& J. P. Barreiros. 2008. Feeding strategy and trophic ontogeny in Epinephelus marginatus (Serranidae) from Southern Brazil. Cybium, 32(1): 33-41.

Marino, G., E. Azzurro, A. Massari, M. G. Finoia \& A. Mandich. 2001. Reproduction in the dusky grouper from the southern Mediterranean. Journal of Fish Biology, 58: 909-927.

Paiva, M. P. \& M. F. Andrade-Tubino. 1998. Distribuição e abundância de peixes bentônicos explotados pelos linheiros ao largo do sudeste do Brasil (1986-1995). Revista Brasileira Biologia, 58(4): 619-632.

Pinkas, L., M. S. Oliphant \& I. L. K. Iverson. 1971. Food habits of albacore, bluefin tuna, and bonito in California waters. Fish Bulletin, 152: 1-105.

Reñones, O., N. V. C. Polunin \& R. Goni. 2002. Size related dietary shifts of Epinephelus marginatus in a western Mediterranean littoral ecosystem: an isotope and stomach content analysis. Journal of Fish Biology, 61: 122-137.

Rico, M. R. \& E. M. Acha. 2003. Southernmost occurrence of Ephinephelus marginatus in the south-west Atlantic. Journal of Fish Biology, 63: 1621-1624.

Santos, R. A. \& M. Haimovici. 1997. Reproductive biology of winter-spring spawners of Illex argentinus (Cephalopoda: Ommastrephidae) off southern Brazil. Science Marine, 61: 53-64,

Santos, R. A. \& M. Haimovici. 2002. Cephalopods in the trophic relations off southern Brazil. Bulletin of Marine Science, 71(1): 753-770.

Smith, W. L. \& M. T. Craig. 2007. Casting the Percomorph net widely: the importance of broad taxonomic sampling in the search for the placement of the serranid and percid fishes. Copeia, 2007(1), 35-55.

Zar, J. H. 1994. Biostatistical Analysis. 2a Ed. Prentice Hall, USA. 